\title{
PERBANDINGAN LATIHAN JOGING DAN LOMPAT TALI TERHADAP DENYUT NADI ISTIRAHAT PADA ATLET KLUB BOLA VOLI TARUNA BEKASI
}

\author{
Willy Pradana ${ }^{1}$ \\ Iwan Hermawan ${ }^{2}$, Eko Juli Fitrianto ${ }^{2}$ \\ ${ }^{1}$ Program Studi Ilmu Keolahragaan \\ ${ }^{2}$ Fakultas Ilmu Keolahragaan Universitas Negeri Jakarta, Kampus B, Jakarta
}

\begin{abstract}
Abstrak. Penelitian ini bertujuan untuk mengetahui latihan mana yang lebih efektif antara latihan joging dan latihan lompat tali terhadap denyut nadi istirahat pada Atlet Klub Bola Voli Taruna Kota Bekasi. Pertemuan dilakukan sebanyak 3 kali selama 1 minggu. Total pertemuan latihan berjumlah 18 kali pertemuan. Metode penelitian yang digunakan dalam penelitian ini adalah metode eksperimen. Sampel yang digunakan dalam penelitian ini adalah Atlet Putra Klub Bola Voli Taruna Kota Bekasi yang berjumlah 20 orang. Teknik analisis data yang digunakan adalah teknik statistik dengan uji-t pada taraf signifikan $\alpha=0,05$, teknik analisa data yang digunakan adalah analisa uji-t mulai dari menghitung t-hitung untuk dibandingkan dengan nilai t-tabel pada taraf signifikan 5\%. Data tes akhir latihan joging dan latihan lompat tali diperoleh standar perbedaan antara dua mean $\left(\operatorname{SE} M_{X} M_{Y}\right)=0,47$ nilai tersebut menjadi t-hitung diperoleh $=2,55$. Kemudian hasil perhitungan tersebut diujikan dengan tabel pada derajat kebebasan $(\mathrm{dk})=\left(\mathrm{N}_{1}+\mathrm{N}_{2}\right)-2=(10+10)-2$ dan taraf kepercayaan $\alpha=$ $0,05$ diperoleh nilai kritis t-tabel 2,101 ( $\mathrm{t}$-hitung $=2,55>\mathrm{t}$-tabel $=2,101)$. Dengan demikian terdapat perbedaan yang diperoleh melalui penelitian ini adalah latihan joging lebih efektif dari pada latihan lompat tali terhadap denyut nadi istirahat pada Atlet Klub Bola Voli Taruna Kota Bekasi.
\end{abstract}

Kata Kunci : Latihan, Jogging, Lompat tali, Denyut Nadi Istirahat.

\section{PENDAHULUAN}

Olahraga merupakan suatu kebutuhan jasmani yang diperlukan oleh semua kalangan baik usia muda maupun usia lanjut. Olahraga juga sebuah elemen pada hidup semua orang, tak dapat dipungkiri dari kita kecil sampai dewasa seseorang selalu membutuhkan aktifitas fisik untuk menunjang kesehatan pada tubuh. Untuk mempertahankan kesegaran jasmani maka perlu diberikan suatu latihan sebab latihan merupakan suatu proses untuk meningkatkan atau mempertahankan kesegaran jasmani dan dalam latihan tersebut tentunya tidak lepas dari aturan-aturan yang disesuaikan dengan keadaan atau kondisi fisik manusia itu sendiri. Banyak jenis olahraga yang sederhana yang dapat dilakukan oleh para remaja seperti dengan kegiatan latihan yaitu latihan Joging dan latihan Lompat tali.

Joging merupakan salah satu olahraga yang sederhana, murah dan mudah untuk dilakukan, aman dari resiko terkena cedera yang serius, juga memiliki banyak manfaat bagi kesehatan 
tubuh. Dengan latihan Joging dengan waktu 30-60 menit secara teratur dapat meningkatkan stamina, membantu menurunkan berat badan, memperkuat otot dan meningkatkan kepadatan tulang, mengatasi resiko penyakit, dan mengatasi gangguan tidur. Menurut Sadoso Sumosardjono "Ketika melakukan latihan aerobik (joging) terjadi beberapa perubahan dalam hal fisiologi individu. Sebelum lari, 0,3 liter oksigen per menit yang digunakan tubuh, tetapi setelah melakukan latihan tubuh membutuhkan 3 liter oksigen.

Lompat tali juga merupakan gerakan yang sangat sederhana dan aman untuk dilakukan. Dengan menggunakan skipping yang diayunkan dan melakukan gerakan melompat-lompat di tempat . Manfaat dari lompat tali yakni dapat membakar sejumlah kalori, melatih otot, menurunkan berat badan, mengurangi resiko osteoporosis, meningkatkan stamina, kelenturan, koordinasi dan keseimbangan tubuh, serta dapat mengkombinasikan irama gerakan dan ketepatan waktu. Latihan lompat tali temasuk dalam contoh latihan untuk meningkatkan daya tahan, lebih tepatnya secara khusus untuk melatih daya tahan otot tungkai. Untuk meningkatkan daya tahan otot diperlukan latihan fisik, teratur, terukur, dan terprogram dengan memperhatikan kualitas dan kuantitas latihan.

Dengan berlatih joging atau lompat tali, tubuh akan mengalami perubahan menjadi lebih baik khususnya perubahan pada denyut nadi istirahat. Hasil pengukuran denyut nadi dapat digunakan sebagai evaluasi efisiensi kerja jantung pada aktifitas fisik atau kegiatan jasmani. Bisa dikatakan orang yang terlatih daya tahan jantung dan paruparunya memiliki denyut nadi yang lebih rendah. Sedangkan orang yang memiliki denyut nadi istirahat yang tinggi dalam atau ingin melakukan suatu aktifitas, dapat diktakan orang tersebut tidak terlatih dan dianjurkan untuk tidak melakukan latihan terlebih dahulu.

\section{KAJIAN PUSTAKA}

Latihan. Latihan biasanya didefinisikan sebagai suatu proses sistematis yang dilakukan dalam jangka waktu panjang, berulang-ulang, progresif, dan mempunyai tujuan untuk meningkatkan penampilan fisik. Dalam latihan harus memperhatikan beberapa prinsip-prinsip latihan yang harus dilakukan agar tujuan latihan dapat sesuai dengan harapan, prinsip-prinsip latihan antara lain; Tipe, Intensitas, dan Tempo (Pemanasan, Inti latihan, Pendinginan).

Joging. Lari santai (joging) merupakan satu jenis keterampilan yang melibatkan proses pemindahan posisi badan, dari satu tempat ke tempat lainnya, dengan gerakan yang lebih cepat dari melangkah. Latihan joging sangat bermanfaat salah satunya untuk meningkatkan daya tahan. Pemeriksaan medis menunjukkan bahwa dengan joging secara teratur, jumlah denyutan waktu istirahat dapat menurun. Karena latihan joging yang tergolong latihan kardiovaskular dapat berpengaruh kepada perubahan dalam sistem sirkulasi dimana terjadi peningkatan kerja jantung menjadi lebih baik dalam mengedarkan darah. Terjadinya perubahan morfologi jantung pada bagian bilik kiri menjadi lebih kuat menyebabkan kerja jantung dalam sekali memompa darah menghasilkan jumlah yang lebih besar.

Lompat Tali. Lompat tali merupakan aktifitas akrobik yang dapat meningkatkan kerja jantung dan paru paru menjadi lebih baik. Olahraga lompat tali membuat tubuh bergerak secara dinamis mengikuti ayunan irama gerakan tangan yang memegang grip tali. Menurut Sadoso Sumosardjono "Lompat tali baik sekali bagi kebugaran kita karena menaikkan atau memelihara 
daya tahan (endurance), menguatkan jantung, menguatkan paru-paru, memperbaiki peredaran darah, mengencangkan otot - otot (paha, pantat, dan pergelangan tangan), dan memperbaiki koordinasi". Pada saat melakukan lompat tali, otot yang paling dominan bekerja adalah otot bagian tungkai, yaitu otot gastrocnemius dan quadriceps (otot betis dan otot paha bagian depan). Selain itu, lompat tali adalah salah satu dari bentuk latihan plyometric yang digunakan untuk meningkatkan kondisi fisik terutama yang mengarah pada kemampuan daya ledak.

Denyut Nadi Istirahat. Denyut nadi istirahat adalah pengukuran frekuensi nadi yang dilakukan tidak dalam latihan, atau sebelum melakukan latihan. Hasil pengukuran denyut nadi dapat digunakan sebagai evaluasi efisiensi kerja jantung pada aktifitas fisik atau kegiatan jasmani. Bisa dikatakan orang yang terlatih daya tahan jantung dan paruparunya memiliki denyut nadi yang lebih rendah. Menurut Sadoso Sumosardjono "Frekuensi denyut nadi istirahat tiap tingkat usia berbeda, dengan anak-anak denyut nadi istirahatnya lebih tinggi dari orang dewasa". Adapun menurut Arie S. Sutopo cara mengetahui dan menghitung denyut nadi yang terdapat dalam Penuntun Praktikum Ilmu Faal, yaitu :

a. Radial Pulse Rate : palpasi sentuh dengan menggunakan ujung jari telunjuk dan jari tengah arteri radialis kearah distal dibagian ujung (di daerah pergelangan tangan sebelah kiri).

b. Carotid Pulse Rate : palpasi daerah leher dibawah telinga dan rahang. Jangan menekan terlalu kuat, karena penekanan kuat arteri karotis dapat menyebabkan efek hambatan (inhibisi) pada jantung.

c. Stethoscope Heart Rate : kontraksi otot jantung dapat pula didengar dengan enggunakan alat bantu stetoskop.

d. Pulse Meter : pengukuran denyut nadi dapat dilakukan pula melalui permukaan telapak tangan. Kedua telapak tangan harus dalam keadaan bersih dan dalam keadaan normal (tidak sehabis latihan atau digosokgosok).

Dengan melakukan aktifitas joging dan lompat tali yang memiliki gerakan yang berbeda, untuk joging gerakannya rileks. Sedangkan untuk lonpat tali, gerakannya hanya di tempat dan menyebabkan ketegangan otot. Sehingga denyut nadi saat melakukan joging lebih cepat dibandingkan dengan lompat tali, yang mengakibatkan penurunan denyut nadi istirahat lebih banyak dari pada saat melakukan lompat tali.

Pada usia remaja ini aktifitas fisik dengan berolahraga seperti joging dan lompat tali sangat diperlukan dalam menunjang perubahan fisik dan kemampuan fungsi organ kearah yang lebih baik. Dengan olahraga teratur dalam waktu seminggu tiga kali dengan lama latihan selama $30-60$ menit dengan intensitas yang sesuai yaitu 70$85 \%$ dari denyut nadi maksimal agar olahraga yang dilakukan dapat mencapai tujuan yang diharapkan.

Dengan Latihan daya tahan aerobik akan menyebabkan adaptasi kardiovaskuler dan sistem respirasi yang sangat diperlukan atlet bola voli untuk menunjang kemampuan peningkatan fisik. Diperlukan daya tahan jantung yang baik untuk dapat bermain secara maksimal dalam durasi permainan yang cukup panjang

\section{METODE}

Metode penelitian yang digunakan peneliti adalah metode eksperimen. Sugiyono mengartikan "Eksperimen sebagai metode penelitian yang digunakan untuk mencari pengeruh 
perlakuan tertentu terhadap yang lain dalam kondisi yang terkendalikan". Dalam penelitian ini peneliti menggunakan" Two-Group Design" dengan variabel bebas pada penelitian ini adalah latihan joging dan lompat Tali, sedangkan variabel terikatnya adalah denyut nadi istirahat. Sampel dilakukan dengan teknik "Purposive Sampling". Sampel dalam penelitian ini adalah berdasarkan kriteria usia 15-18 tahun, maka sampel yang digunakan berjumlah 20 orang atlet putra Klub Bola Voli Taruna Kota Bekasi. Tempat penelitian di Klub Bola Voli Taruna, Jl. Cemara E18 no. 17 RT 17/014, Pondok Ungu Permai, Bekasi Utara.

Dalam penelitian ini data yang diambil yaitu denyut nadi istirahat dengan cara para testee melakukan aktivitas latihan joging dan lompat Tali. Sebelumnya peneliti mengambil data dengan melakukan pretest dan posttest pada sampel penelitian.

Pretest untuk joging, tes yang dilakukan adalah maximal aerobic speed yaitu dengan melakukan lari sejauh 1000 meter. Setelah itu akan diambil kecepatan rata-rata yang selanjutnya akan dipakai sebagai batas kecepatan dalam melakukan latihan joging. Posttest dilakukan dengan cara yang sama setelah selesai melakukan program latihan joging.

Sedangkan pretest untuk latihan lompat tali, tes yang akan dilakukan adalah dengan melakukan lopat tali yang kecepatannya diatur oleh metronome dan dilakukan selama mungkin oleh sampel. Posttest untuk latihan lompat tali dilakukan dengan cara yang sama setelah selesai melakukan program latihan lompat tali.

Program latihan joging dan lompat tali yang akan dilakukan adalah sebagai berikut : a) Pengukuran dilakukan dalam keadaan istirahat, pada saat sebelum memulai latihan.

b) Testee meraba bagian arteri radialis sampai denyut nadinya teraba.

c) Kemudian testee melaporkan jumlah denyut nadinya sendiri selama 30 detik.

d) Kemudian setiap testee melaporkan jumlah denyut nadinya pada saat akan melakukan latihan jogging dan lompat tali, kemudian hasilnya dikalikan dua dan di catat pada kertas pencatat.

Adapun langkah - langkah mengikuti penelitian, yaitu :

a. Pada Joging

1) Testee diperiksa kesehatannya sebelum mengikuti penelitian ini.

2) Testee diambil nadinya setiap awal latihan.

3) Melakukan pemanasan dan peregangan selama 5-10 menit sebelum melakukan latihan Joging.

4) Melakukan Joging dengan kecepatan 3-5 km/jam dengan durasi waktu 30 - 60 menit.

5) Jika selama melakukan latihan Joging denyut nadi tetap atau tidak ada peningkatan, maka kecepatannya akan ditambah.

6) Pendinginan selama 5 menit.

b. Pada Lompat Tali

1) Testee diperiksa kesehatannya sebelum mengikuti penelitian ini.

2) Testee diambil nadinya setiap awal latihan.

3) Melakukan pemanasan dan peregangan selama 5-10 menit sebelum melakukan latihan lompat tali.

4) Melakukan Lompat tali selama 3 menit x 10 - 20 set dengan istirahat tiap set 2 menit.

5) Pendinginan selama 5 menit. 
HASIL dan PEMBAHASAN Deskripsi Data

Pengumpulan data digunakan sebagai data penelitian yang diperoleh dari tes awal dan tes akhir denyut nadi istirahat berdasarkan pengamatan dari hasil latihan joging dan latihan lompat tali yang benar.

\section{Data Hasil Tes Latihan Joging}

Data tes awal denyut nadi istirahat pada kelompok latihan joging diperoleh skor level terendah 72 dan skor level tertinggi 84 dengan rata-rata $\left(\mathrm{x}_{1}\right)=80,0$ simpangan baku $\left(\mathrm{S} x_{1}\right)=3,65$ dan standar kesalahan mean $\left(\mathrm{SEm} x_{1}\right)=1,21$.

Tabel 1. Distribusi Frekuensi Tes Awal Kelompok Latihan Joging

\begin{tabular}{c|c|c|c|c}
\multirow{2}{*}{ No } & Kelas & Nilai & \multicolumn{2}{|c}{ Frekuensi } \\
\cline { 4 - 5 } & Interval & Tengah & Absolut & Relatif \\
\hline 1 & $71-73$ & 72 & 1 & $10 \%$ \\
\hline 2 & $74-76$ & 75 & - & - \\
\hline 3 & $77-79$ & 78 & 3 & $30 \%$ \\
\hline 4 & $80-82$ & 81 & 4 & $40 \%$ \\
\hline 5 & $83-85$ & 84 & 2 & $20 \%$ \\
\hline \multicolumn{4}{c}{ Sumber: Hasil Pengolahan Data } \\
\hline
\end{tabular}

Data tes akhir denyut nadi istirahat pada kelompok latihan joging diperoleh skor level terendah 72 dan skor level tertinggi 78 dengan rata-rata $\left(\mathrm{x}_{2}\right)=74,6$ simpangan baku $\left(\mathrm{S} x_{2}\right)=3,83$ dan standar kesalahan mean $\left(\operatorname{SEm} x_{2}\right)=1,27$.

Tabel 2. Distribusi Frekuensi Tes Akhir Kelompok Latihan Joging

\begin{tabular}{|c|c|c|c|c|}
\hline \multirow{2}{*}{ No } & \multirow{2}{*}{$\begin{array}{c}\text { Kelas } \\
\text { Interval }\end{array}$} & \multirow{2}{*}{$\begin{array}{c}\text { Nilai } \\
\text { Tengah }\end{array}$} & \multicolumn{2}{|c|}{ Frekuensi } \\
\hline & & & Absolut & Relatif \\
\hline 1 & $67-69$ & 68 & 1 & $10 \%$ \\
\hline 2 & $70-72$ & 71 & 2 & $20 \%$ \\
\hline 3 & $73-75$ & 74 & 2 & $20 \%$ \\
\hline 4 & $76-78$ & 77 & 5 & $50 \%$ \\
\hline 5 & $79-81$ & 80 & - & - \\
\hline & & & 10 & $100 \%$ \\
\hline
\end{tabular}

\section{Data Hasil Tes Latihan Lompat Tali}

Data tes awal denyut nadi istirahat pada kelompok latihan lompat tali diperoleh skor level terendah 72 dan skor level tertinggi 84 dengan rata-rata $\left(\mathrm{y}_{1}\right)=78,4$ simpangan baku $\left(\mathrm{S} y_{1}\right)=3,97$ dan standar kesalahan mean $\left(\operatorname{SEm} y_{1}\right)=$ 1,32 .

Tabel 3. Distribusi Frekuensi Tes Awal Kelompok Latihan Lompat Tali

\begin{tabular}{c|c|c|c|c}
\multirow{2}{*}{ No } & \multirow{2}{*}{$\begin{array}{c}\text { Kelas } \\
\text { Interval }\end{array}$} & Nengai & \multicolumn{2}{|c}{ Frekuensi } \\
\cline { 4 - 5 } & Tengah & Absolut & Relatif \\
\hline 1 & $71-73$ & 72 & 1 & $10 \%$ \\
\hline 2 & $74-76$ & 75 & 2 & $20 \%$ \\
\hline 3 & $77-79$ & 78 & 2 & $20 \%$ \\
\hline 4 & $80-82$ & 81 & 4 & $40 \%$ \\
\hline 5 & $83-85$ & 84 & 1 & $10 \%$ \\
\hline & \multicolumn{3}{c}{ Sumber: Hasil Pengolahan Data }
\end{tabular}

Data tes akhir denyut nadi istirahat pada kelompok latihan lompat tali diperoleh skor level terendah 68 dan skor level tertinggi 80 dengan rata-rata $\left(\mathrm{y}_{2}\right)=74,0$ simpangan baku $\left(\mathrm{Sy}_{2}\right)=4,32$ dan standar kesalahan mean $\left(\mathrm{SEmy}_{2}\right)=$ 1,44 .

Tabel 4. Distribusi Frekuensi Tes Akhir Kelompok Latihan Lompat Tali

\begin{tabular}{c|c|c|c|c}
\multirow{2}{*}{ No } & Kelas & Nilai & \multicolumn{2}{|c}{ Frekuensi } \\
\cline { 4 - 5 } & Interval & Tengah & Absolut & Relatif \\
\hline 1 & $67-69$ & 68 & 2 & $20 \%$ \\
\hline 2 & $70-72$ & 71 & 1 & $10 \%$ \\
\hline 3 & $73-75$ & 74 & 2 & $20 \%$ \\
\hline 4 & $76-78$ & 77 & 4 & $40 \%$ \\
\hline 5 & $79-81$ & 80 & 1 & $10 \%$ \\
\hline & \multicolumn{3}{c}{ Sumber: Hasil Pengolahan Data }
\end{tabular}

\section{Pengujian Hipotesis}

\section{Hasil Tes Awal Dan Tes Akhir Kelompok Latihan Joging.}

Hasil analisis dari tes awal dan tes akhir hasil denyut nadi istirahat dengan menggunakan latihan joging diperoleh nilai rata-rata deviasi $\left(\mathrm{M}_{\mathrm{D}}\right)=5,40$ simpangan baku $\left(\mathrm{S}_{\mathrm{D}}\right)=1,34$ dan standar kesalahan mean $\left(\mathrm{SE}_{\mathrm{MD}}\right)=0,44$. Hasil tersebut menghasilkan t-tabel pada derajat kebebasan $(\mathrm{dk})=\mathrm{n}-1=10-1=$ 9 dengan taraf kepercayaan $(\alpha)=0,05$ diperoleh nilai kritis t-tabel $=2,262$. Dengan demikian nilai t-hitung lebih besar dari t-tabel (t-hitung $=12,27>\mathrm{t}$ tabel $=2,262$ ).

Berdasarkan analisis data tersebut dapat disimpulkan hipotesis nol $\left(\mathrm{H}_{0}\right)$ ditolak, hipotesis kerja $\left(\mathrm{H}_{1}\right)$ diterima, 
berarti latihan joging mempunyai pengaruh terhadap denyut nadi istirahat.

\section{Hasil Tes Awal Dan Tes Akhir Kelompok Latihan Lompat Tali.}

Hasil analisis dari tes awal dan tes akhir hasil denyut nadi istirahat dengan menggunakan latihan lompat tali diperoleh nilai rata-rata deviasi $\left(\mathrm{M}_{\mathrm{D}}\right)=$ 4,20 simpangan baku $\left(\mathrm{S}_{\mathrm{D}}\right)=0,60$ dan standar kesalahan mean $\left(\mathrm{SE}_{\mathrm{MD}}\right)=0,20$. Hasil tersebut menghasilkan t-tabel pada derajat kebebasan $(\mathrm{dk})=\mathrm{n}-1=$ $10-1=9$ dengan taraf kepercayaan $(\alpha)$ $=0,05$ diperoleh nilai kritis $\mathrm{t}$-tabel $=$ 2,262. Dengan demikian nilai t-hitung lebih besar dari t-tabel (t-hitung $=21>\mathrm{t}$ tabel $=2,262$ ).

Berdasarkan analisis data tersebut dapat disimpulkan hipotesis nol $\left(\mathrm{H}_{0}\right)$ ditolak, hipotesis kerja $\left(\mathrm{H}_{1}\right)$ diterima, berarti latihan lompat tali mempunyai pengaruh terhadap denyut nadi istirahat.

\section{Hasil Tes Akhir Kelompok Latihan Joging dan Latihan Lompat Tali.}

Data tes akhir latihan joging dan latihan lompat tali diperoleh standar perbedaan antara dua mean $\left(\mathrm{SE}_{X} M_{Y}\right)=$ 0,47 . Nilai tersebut diujikan dengan tabel pada derajat kebebasan $(\mathrm{dk})=\left(\mathrm{N}_{1}+\mathrm{N}_{2}\right)$ $-2=(10+10)-2$ dan taraf kepercayaan $(\alpha)=0,05$ diperoleh nilai kritis t-tabel 2,101 ( $\mathrm{t}$-hitung $=2,55>\mathrm{t}$ tabel $=2,101)$.

Berdasarkan hasil analisa data tersebut maka $\mathrm{H}_{0}$ ditolak dan $\mathrm{H}_{1}$ diterima sehingga dapat disimpulkan bahwa latihan joging lebih efektif dari pada latihan lompat tali terhadap denyut nadi istitahat pada atlet klub Bola Voli Taruna Kota Bekasi.

\section{Pembahasan}

Sesuai dengan latar belakang, rumusan masalah, tujuan dan hasil penelitian, serta berdasarkan hipotesis yang diambil bahwa latihan joging dan lompat tali mengalami perbedaan yang signifikan terhadap denyut nadi istirahat, yaitu dengan melakukan perlakuan (treatment) selama 6 minggu dengan frekuensi latihan selama 3 kali dalam seminggu.

Berdasarkan hasil penelitian ini, diketahui bahwa latihan joging termasuk dalam continuous training dan tergolong latihan untuk meningkatkan kardiovaskular dimana sampel melakukan kerja joging selama $30-60$ menit tanpa berhenti. Sedangkan latihan lompat tali termasuk dalam interval training antara kerja diselingi oleh waktu istirahat dengan kerja lompat tali selama 3 menit dan istirahat selama 2 menit dan tergolong latihan yang secara khusus dapat meningkatkan daya tahan otot (muscle endurance). Terlihat bahwa kedua aktivitas ini berbeda karakter dan masing-masing memiliki keunggulan dan kelemahan jika kedua latihan ini dibandingkan.

Latihan joging yang merupakan continuous training memiliki keunggulan dimana sampel melakukan kerja joging tanpa berhenti sampai dengan waktu yang ditentukan yang menyebabkan denyut nadi latihan terjaga kondisinya atau stabil selama melakukan kerja joging. Sedangkan latihan lompat tali yang bersifat interval training mempunyai kelemahan dimana pada saat masuk waktu istirahat antar set denyut nadi latihan dikhawatirkan mengalami penurunan. Namun latihan lompat tali dapat dikategorikan sebagai interval continuous training karena dilakukan dalam durasi yang yang panjang atau lama. Sehingga latihan joging akan lebih efektif dari pada latihan lompat tali terhadap kondisi denyut nadi istirahat.

Meskipun terdapat perbedaan dalam jenis latihan, joging dan lompat tali merupakan latihan dengan intensitas rendah dimana sumber energi yang disediakan melalui sistem energi aerobik. Olahraga aerobik bertujuan 
untuk meningkatkan denyut jantung untuk jangka waktu tertentu, setelah melakukan program latihan joging dan lompat tali, diharapkan terjadinya perubahan morfologi pada jantung. Bagian jantung yang memompakan darah yaitu bagian ventrikel akan lebih kuat, sehingga terjadi efisiensi kerja jantung yang lebih baik setelah melakukan latihan joging dan lopat tali. Hal ini dikarenakan orang yang terlatih daya jantung dan parunya akan memiliki denyut nadi istirahat yang rendah sebab adanya peningkatan volume darah yang dipompa jantung dalam sekali denyutnya, dan distribusi darah dari jantung menjadi lebih cepat dan lancar.

\section{PENUTUP}

Kesimpulan. Berdasarkan masalah yang dikemukakan serta didukung oleh deskripsi teori dan kerangka berpikir serta analisis data, maka hasil tersebut dapat disimpulkan bahwa :

1. Terdapat perbedaan terhadap denyut nadi istirahat pada atlet Klub Bola Voli Taruna Kota Bekasi setelah diberikan latihan joging.

2. Terdapat perbedaan terhadap denyut nadi istirahat pada atlet Klub Bola Voli Taruna Kota Bekasi setelah diberikan latihan lompat tali.

3. Latihan Joging lebih efekif dari pada latihan lompat tali terhadap denyut nadi istirahat pada atlet Klub Bola Voli Taruna Kota Bekasi

Saran. Dari hasil penelitian ini, peneliti ingin menyampaikan saran-saran sebagai berikut :

1. Kepada Atlet Klub Bol Voli Taruna Kota Bekasi sebaiknya tetap menjaga kebugaran jasmaninya dengan melakukan kegiatan olahraga rutinnya, seperti
: joging dan lompat tali agar denyut nadi istirahat yang sudah dilatih tetap menjadi lebih baik lagi.

2. Kepada Atlet Klub Bola Voli Taruna Kota Bekasi dilihat dari hasil penelitian, dianjurkan untuk lebih memilih melakukan aktivitas joging sebagai pilihan untuk menjaga agar tetap menjadi lebih baik untuk denyut nadi istirahatnya.

3. Kepada pelatih Klub Bola Voli Taruna Kota Bekasi agar tetap mengingatkan para Atlet untuk mengecek target denyut latihannya.

\section{DAFTAR PUSTAKA}

Anas Sudjiono. Pengantar Statistik Pendidikan. Yogyakarta: Andi, 2000.

Arie S. Sutopo. Buku Penuntun Praktikum Ilmu Faal Dasar Kerja. Jakarta: FIK UNJ, 2002.

Astra Parahita. Pengaruh Latihan Fisik Terprogram Terhadap Daya Tahan Otot pada Siswi Sekolah Bola Voli Tugu Muda Searang Usia 9-12 Tahun. Semarang: Laporan Penelitian Universitas Diponegoro, 2009.

Bompa, Tudor O. Periodization Theory and Methodology of Training. New York: Human Kinetics, 1999.

Depdiknas. Pedoman dan Modul Pelatihan Kesehatan Olahraga bagi Pelatihan Olahragawan Pelajar. Jakarta: Depdiknas, 2000.

Hannam S. Women's Basketball Jump Training Circuit. Indiana 47405: Departement Indiana University, Assembly Hall Boomington, 1985.

Sadoso Sumosardjono. Olahraga dan Kesehatan. Jakarta: Pustaka Kartini, 1989. 
Pengetahuan Praktis Kesehatan dalam Olahraga 3. Jakarta: PT Gramedia Pustaka Utama, 1993.

S. Nasution. Metodelogi Research. Jakarta: Bumi Aksara, 2002.

Sugiyono. Metode Penelitian Kuantitatif, Kualitatif, dan $R \& D$. Bandung: CV Alfabeta, 2011.

Yudha M Saputra. Dasar-dasar Keterampilan Atletik. Jakarta: Direktorat Jendral Olahraga, 2001. 